\title{
EFFECTS OF SPINAL MANIPULATION IN PATIENTS WITH MECHANICAL NECK PAIN
}

\author{
EFEITO DA MANIPULAÇÃO VERTEBRAL EM PACIENTES COM CERVICALGIA MECÂNICA
}

EFECTOS DE LA MANIPULACIÓN VERTEBRAL EN PACIENTES CON CERVICALGIA MECÁNICA

Diana Gregoletto ${ }^{1}$, Cruz Miguel Cendán Martínez ${ }^{1}$

\begin{abstract}
Objective: To analyse changes in the range of motion (ROM) and pain after spinal manipulation of the cervical spine and thoracic spine in subjects with mechanical neck pain. Methods: Spinal manipulations were performed in the cervical and thoracic spine with the Gonstead and Diversified DTV techniques. To assess cervical ROM an inclinometer was used. Cervical pain was assessed by Visual Analogue Scale (VAS). The participation of 73 patients was obtained. Ages ranged from 18 to 63 years, with an average of 42.27 years. The subjects of this study were characterized by having mechanical neck pain and restricted cervical ROM. Results: We observed a reduction in the intensity of pain perceived by patients and increased cervical ROM. There were significant differences between pre-treatment values (first visit) and the fifth and tenth visits $(p<0.01)$, and between the fifth and tenth visits $(p<0.01)$ in all parameters except in the cervical extension of $70^{\circ}$. Conclusions: The results of this study suggest that spinal manipulation of the cervical and thoracic regions with the Gonstead and Diversified DTV techniques could subjectively reduce pain and produce considerable increase in cervical ROM in adults with mechanical neck pain.
\end{abstract}

Keywords: Neck pain; Range of motion; Chiropractic; Spinal manipulation; Cervical vertebrae.

\section{RESUMO}

Objetivo: Analisar as alterações da amplitude de movimento (ADM) e da dor após manipulação da coluna cervical e dorsal, em indivíduos com cervicalgia mecânica. Métodos: Foram realizadas manipulações na coluna cervical e dorsal com as técnicas Gonstead e Diversificada DTV. Para avaliar a ADM cervical, utilizou-se o instrumento inclinômetro. A dor na coluna cervical foi avaliada por meio da Escala Visual Analógica (EVA). Obteve-se a participação de 73 pacientes. As idades oscilaram entre 18 e 63 anos, com média de 42,27 anos. Os indivíduos do estudo foram caracterizados por apresentar cervicalgia mecânica e restrição da ADM cervical. Resultados: Constatou-se redução da intensidade da dor percebida pelos pacientes e aumento da ADM cervical. Houve diferenças significativas entre os valores pré-tratamento (primeira consulta) e na quinta e décima consultas $(p<0,01)$ e entre a quinta e décima consultas $(p<0,01)$ em todos os parâmetros, exceto na extensão cervical de $70^{\circ}$. Conclusão: Os resultados deste estudo sugerem que a manipulação vertebral da coluna cervical e dorsal com as técnicas Gonstead e Diversificada DTV poderiam ocasionar redução subjetiva da dor e produzir aumento considerável na ADM cervical em adultos com cervicalgia mecânica.

Descritores: Cervicalgia; Amplitude de movimento articular; Quiroprática; Manipulação da coluna; Vértebras cervicais.

\section{RESUMEN}

Objetivos: Analizar las alteraciones en la amplitud de movimiento (ADM) y algias tras la manipulación vertebral en la columna cervical y dorsal, en sujetos con cervicalgia mecánica. Métodos: Fueron realizadas manipulaciones en la columna cervical y dorsal con las técnicas Gonstead y Diversificada DTV. Para evaluar la ADM cervical se utilizó un inclinómetro. El dolor en la columna cervical, fue evaluado mediante la Escala Visual Analógica (EVA). Se obtuvo la participación de 73 pacientes. Las edades oscilaron entre los 18 y los 63 años, con una edad promedio de 42,27 años. Los sujetos de esta investigación se caracterizaron por presentar cervicalgia mecánica y restricción en la ADM cervical. Resultados: Se observó una reducción en la intensidad del dolor percibida por los pacientes y un aumento en la $A D M$ cervical, obteniéndose diferencias significativas entre los valores pretratamiento (primera cita) y las citas quinta y décima $(p<0,01)$, y entre las citas quinta y décima $(p<0,01)$ en todos los parámetros excepto en extensión cervical $70^{\circ}$. Conclusión: Los resultados de este estudio sugieren que la manipulación vertebral, con las técnicas Gonstead y Diversificada DTV, en la columna cervical y dorsal, podría provocar una reducción subjetiva del dolor y producir un aumento considerable en la ADM cervical en adultos con cervicalgia mecánica.

Descriptores: Dolor de cuello; Rango del movimiento articular; Quiropráctica; Manipulación espinal; Vértebras cervicales.

INTRODUCTION

Mechanical neck pain, i.e. the presence of acute or chronic pain in the cervical region, is located in the posterior and posterolateral parts of the neck, and is sometimes accompanied by remote referred pain to the upper limb or head, or symptoms of vertigo. ${ }^{1}$ It is believed to be caused by a mechanical dysfunction involving various anatomical structures of the cervical spine, essentially of musculoskeletal origin, causing restricted movement and pain. The majority of cases of neck pain originate in mechanical factors: repetitive movements, lack of work breaks, static jobs, and holding the head and/or arms in the same position for long periods of time. ${ }^{2-4}$

The precise nature of the cause of mechanical neck pain is not

1. Universidad de Granada, Granada, España.

Study conducted at Universidad de Granada, Granada, Spain.

Correspondence: Calle Mainake, 7. 29670. San Pedro de Alcántara, Málaga, Spain. digregoletto@gmail.com 
clear; however, it has been attributed to stimulation of the afferent nociceptive fibers present in the cervical interapophyseal joints, intervertebral discs, paravertebral muscles, and other soft tissues. ${ }^{5}$ Recent studies have suggested that the cervical interapophyseal joints may be the main cause of neck pain. ${ }^{6}$

According to the World Health Organization ${ }^{7} 50 \%$ of adults experience neck pain during their lifetime. The frequent presence of neck pain in the general population is estimated at between $10 \%$ and $15 \%$, with women being more commonly affected than men. More than a third of patients who visit the doctor with neck pain present symptoms lasting more than six months, or recurring symptoms. ${ }^{8,9}$

Reduction in range of movement (ROM) of the neck is a frequent finding in individuals with mechanical neck pain. ${ }^{10-15}$

Recent studies have suggested that manipulative techniques focused on the thoracic region may be effective in the treatment of neck pain. ${ }^{16,17}$ However, we have not found any scientific evidence in studies evaluating the effect of vertebral manipulation in adults with mechanical neck pain using the Gonstead technique in the cervical spine, and the Diversified Double Transverse (DTV) technique in the thoracic spine.

The aim of this study was to evaluate changes in range of movement and pain in the cervical spine following vertebral manipulation in the cervical and thoracic spine.

\section{METHODS}

The subjects were characterized as presenting mechanical neck pain, defined as specific pain located centrally or bilaterally on the back of the neck, mainly in the area between the upper nuchal line and the tip of the first thoracic spinous process. The participation of 73 patients was obtained: 37 women and 36 men. Ages ranged from 18 to 63 years, with an average age of 42.27 years. The study was approved by the Institutional Review Board. All the subjects signed the Informed Consent Form. The exclusion criteria were: failure to attend all the trial visits, having suffered some trauma during the study period, individuals diagnosed with fracture, dislocation, joint hypermobility, rupture of the soft tissues, cancer and surgical history involving the joints studied, as well as those who began during chiropractic treatment, use of analgesics, anti-inflammatories, or other therapeutic treatment for the complaint in question.

The procedures used in the first visit were: anamnesis, physical examination with orthopedic tests on the cervical spine, tendon reflexes, sensory and motor evaluation of the upper extremities, vascular tests, vital signs, assessment of ROM/neck pain and evaluation of imaging exams of the cervical spine, ${ }^{18,19}$ always performed by the same person. ${ }^{20}$

For the evaluation of cervical ROM, a manual inclinometer (TECSYMP) was used, with a measuring range of $0^{\circ}$ to $180^{\circ}$. During the cervical ROM test, the subjects sat in a chair with a backrest, in a relaxed position, facing forwards (neutral position $0^{\circ}$ ). The range of movement between the neutral position and the maximum angular displacement of the head was recorded. The subjects were asked to move their heads in maximum flexion, extension, right and left lateral flexion, and right and left rotation. Three consecutive movements performed in each direction, taking the mean value as the final measurement. The procedure was repeated on the first, fifth and tenth visits.

The evaluation of pain was carried out using a visual analogue scale (VAS) of pain, and was performed on the $1^{\text {st }}, 5^{\text {th }}$ and $10^{\text {th }}$ visits. The treatment was based on correcting the segments that presented highest fixation or limitation of movement in the cervical and thoracic spines, detected by static and dynamic palpation.

\section{Gonstead Technique}

The Gonstead technique (Figure 1) chosen for correction of the segments with higher fixation or limitation of motion of the cervical spine was the Cervical Chair (CC) technique. The technique was performed with the patient sitting in a chair with a backrest, in a

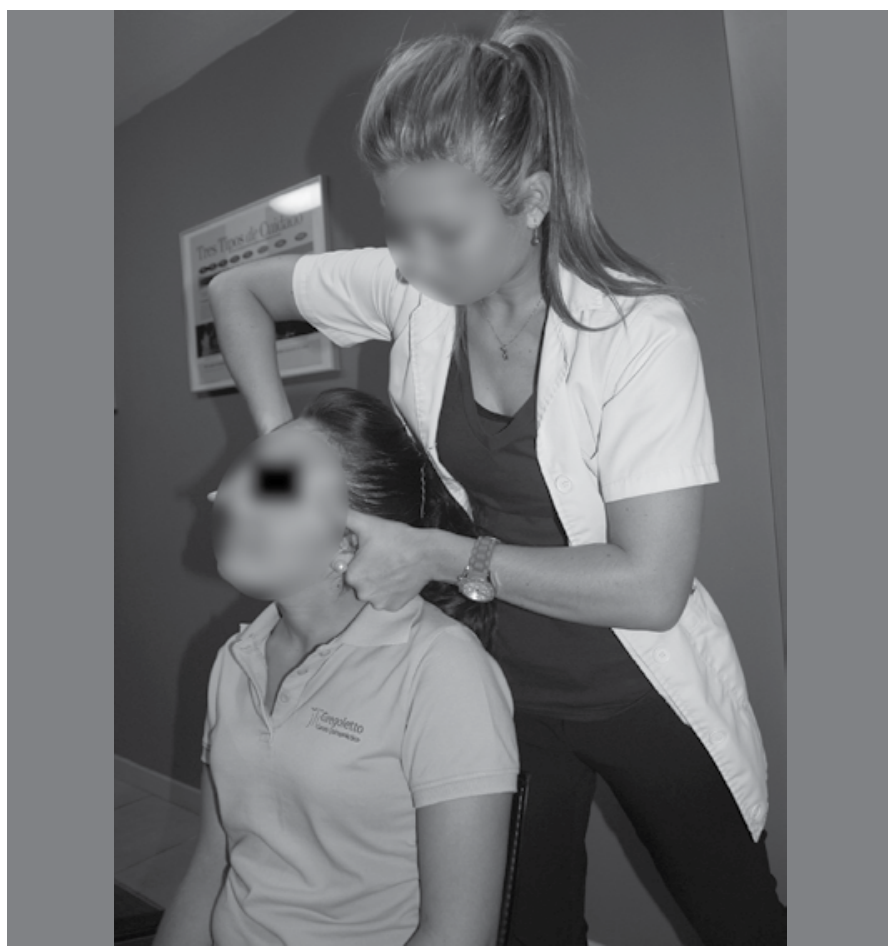

Figure 1. Gonstead CC Technique.

relaxed position, with arms and legs extended and facing forwards.

The chiropractor was positioned behind the patient, favoring the side of the rotation of the spinous process (right or left) of the vertebra to be manipulated, with the right leg (in rotations of the spinous process to the right) or left (in rotations to the left) backwards.

The contact hand was on the spinous process to the left (rotations to the left) or right. The focal point was the right or left edge of the second finger of the right or left hand. The exact point was the left (or right) inferior posterior view of the spinous process posterior inferior view. The third finger of the opposite hand (right or left) stabilized the opposite transverse apophysis of the segment below the one being manipulated. A gentle inclination to the left (or right) was performed until slight tension was achieved, and an impulse was applied, without rotation of the cervical spine, with a movement from posterior to anterior, inferior to superior, right to the left (in the case of rotation of the spinous apophysis to the right) and inwards. The impulse was high velocity and low amplitude. ${ }^{20-22}$

\section{DTV Diversified technique}

The Diversified technique (Figure 2) chosen for correction of the segments with higher fixation or limitation of movement in the thoracic spine was the Double Transverse technique (DTV). The technique was performed with the patient in the prone position, with chiropractor next to the rotation of the vertebral body of the segment to be manipulated. The pisiform of the chiropractor's lower hand was in contact with the transverse apophysis of the side of the rotation of the vertebral body, and the upper hand was in contact with the spinous apophysis on the opposite side, i.e. on the side of the rotation of the spinous apophysis. The upper hand stabilized the segment to be set, and the lower hand corrected it through an impulse. The direction of the impulse was posterior to anterior, and inferior to superior.

The impulse was set and held for two to three seconds, and was performed with high speed and low amplitude. ${ }^{20,22}$

\section{Data recompilation plan}

Data were collected in a private chiropractic center. Chiropractic adjustments were performed by the investigator of this study, which has a degree in chiropractic medicine. The chiropractic intervention was therefore standardized for all the patients. 


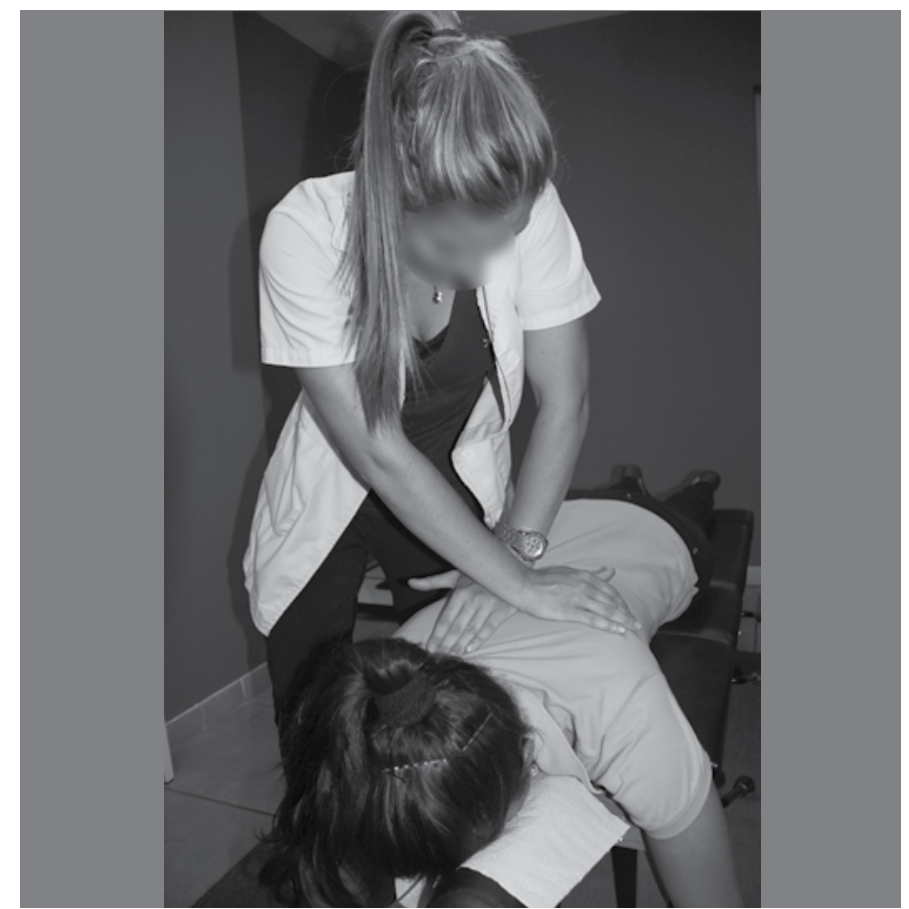

Figure 2. DTV Diversified Technique.

\section{Statistical analysis}

The values and points/bars represented in the graphs show the mean \pm SEM (standard error of the mean) of the scores obtained in each of the parameters evaluated on the different visits. Statistical comparisons were performed using one-way ANOVA for repeated measurements, followed by the Bonferroni test using the statistical program Prism 5.0. Data with alpha error below $5 \%$ were considered significant $(p<0.05)$ and those with an alpha error of less than $1 \%$ $(p<0.01)$ were considered very significant.

\section{RESULTS}

Regarding the effects of cervical ROM in flexion, the averages for the pre-and post-intervention groups were 50.07 and 59.38 degrees, respectively (Figure 3 ). A significant improvement $(p<0.01)$ was obtained, which was dependent on the number of sessions (Figure 3). Figure 4 shows that the averages for the preand post-intervention groups, in the cervical extension, were 64.59 and 69.86 degrees, while on the $5^{\text {th }}$ visit, maximum improvement was almost achieved $(p<0.01)$.

Regarding cervical ROM in right and left later flexion (Figure 5) and right and left rotation (Figure 6), clear statistical significance $(p<0.01)$ was observed in both cases, between the initial values and the intermediate and final values, with ROM increasing to normal values (Figures 5 and 6).

Spinal manipulation produced a significant reduction in scores on the first visit and subsequent visits (Figure 7). Thus, the mean pre-treatment average for the neck pain was 6.33 , with a reduction of almost half after five adjustments in the cervical spine, which was further reduced after ten visits (1.55) (Figure 7). It should be emphasized that there were significant differences not only between $1^{\text {st }}$ and subsequent visits ( $p<0.01$ ), but differences were also obtained in the scores on the $5^{\text {th }}$ and $10^{\text {th }}$ visits $(p<0.01)$, indicating that the higher the number of manipulations, the greater the decrease in pain (Figure 7).

\section{DISCUSSION}

The results of the study showed an increase in cervical mobility, and a subjective reduction in pain after spinal manipulation through the Gonstead and Diversified DTV techniques in the cervical and thoracic spine, in adult patients with mechanical neck pain.

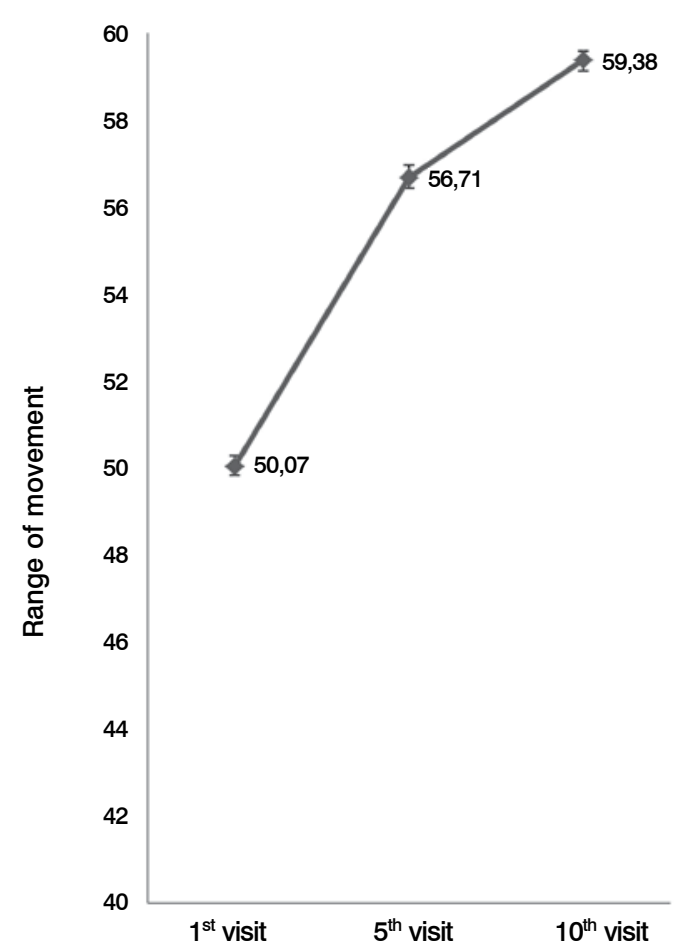

Figure 3. Range of movement of cervical flexion. Statistically significant differences between the 1st visit and the remaining visits; and between the $5^{\text {th }}$ and $10^{\text {th }}$ visits $(p<0.01)$.

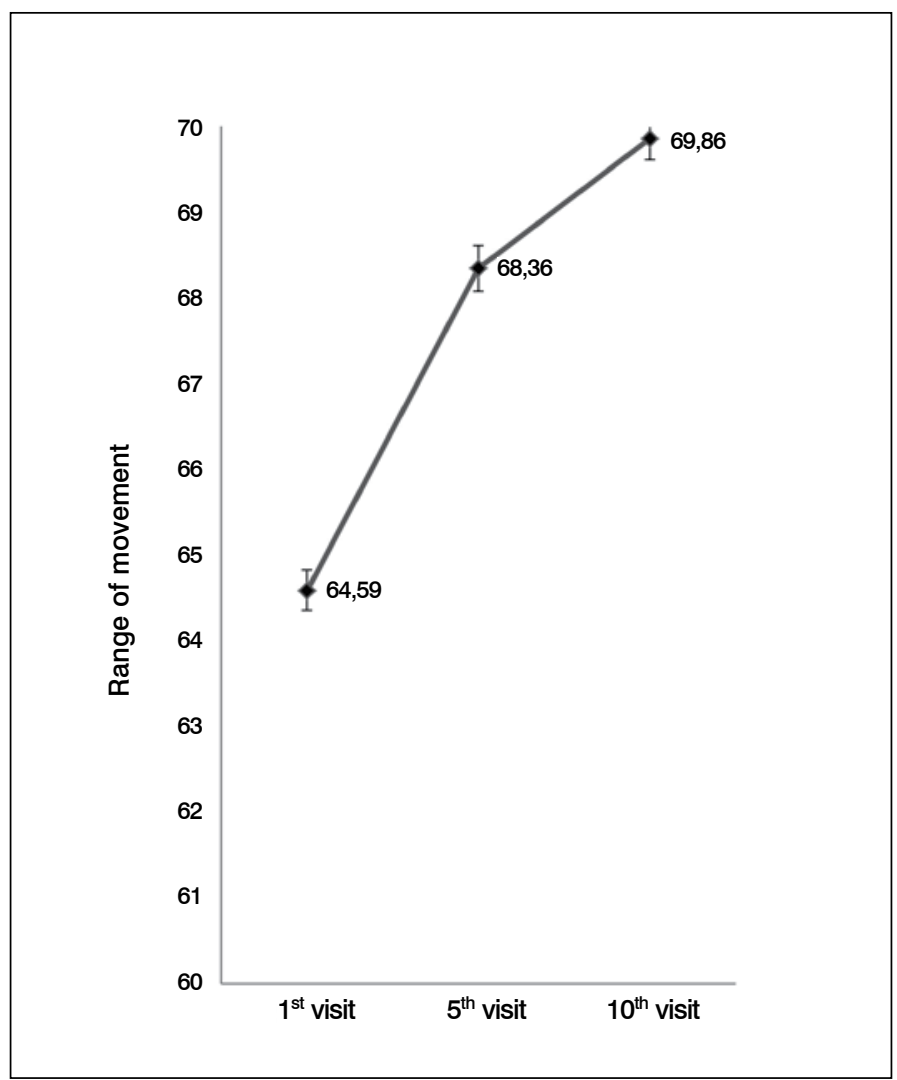

Figure 4. Range of movement of cervical extension. Statistically significant differences between the 1 st visit and the remaining visits $(p<0.01)$. 


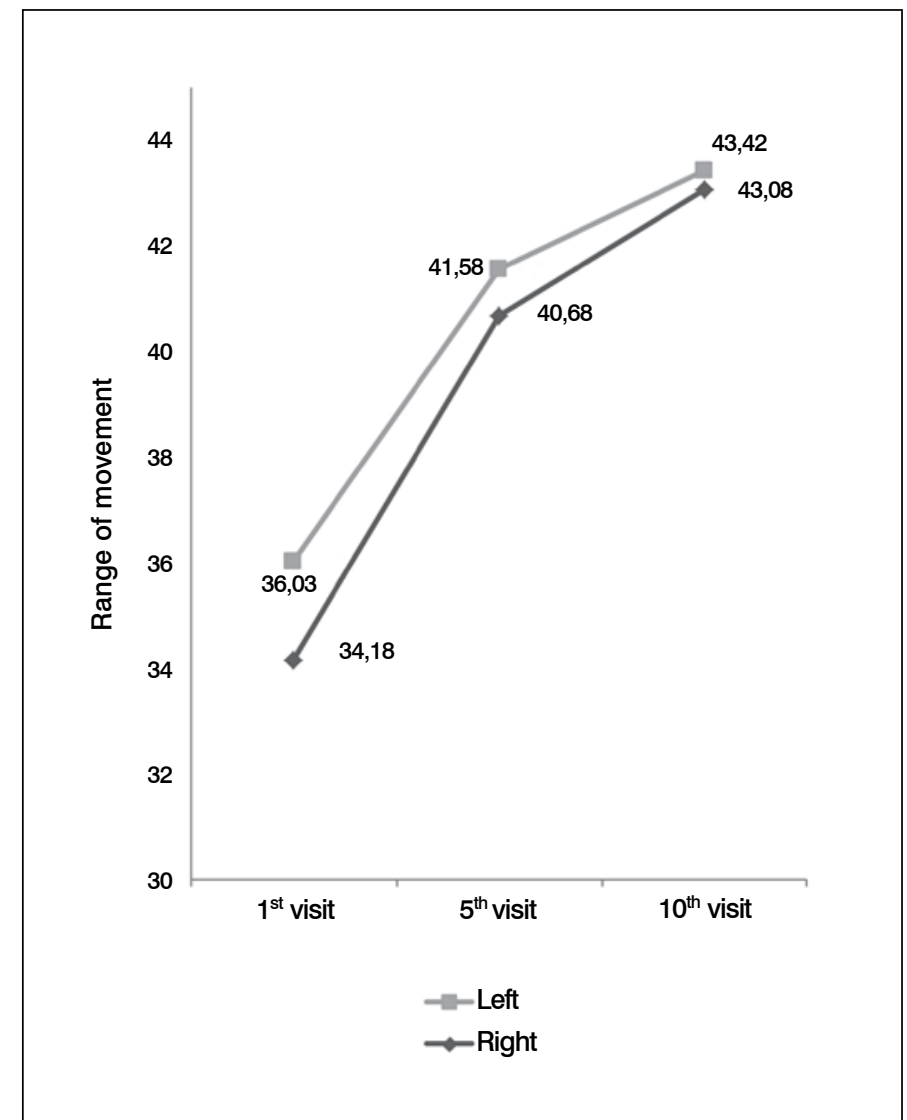

Figure 5. Range of movement of cervical bilateral lateral flexion. Statistically significant differences between the 1st visit and the remaining visits; and between the $5^{\text {th }}$ and $10^{\text {th }}$ visits $(p<0.01)$.

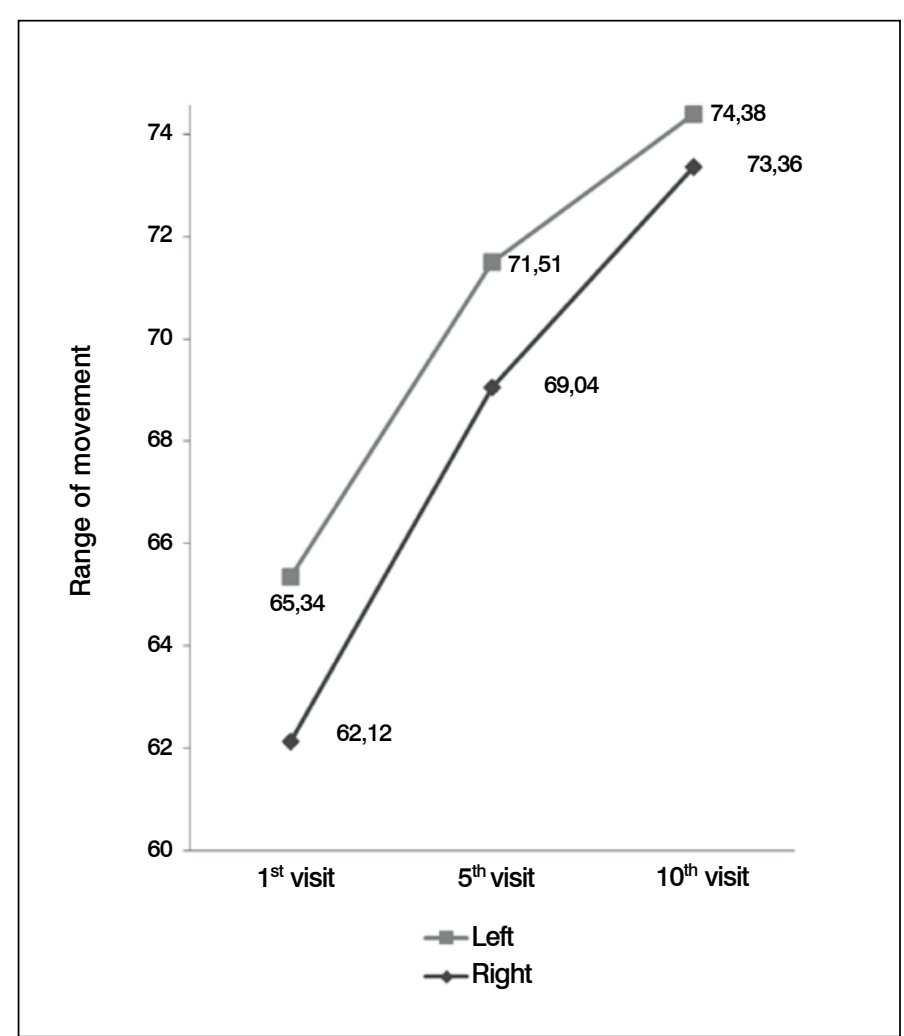

Figure 6. Range of movement of bilateral cervical rotation. Statistically significant differences between the 1st visit and the remaining visits; and the 5th and 10th visits $(p<0.01)$.

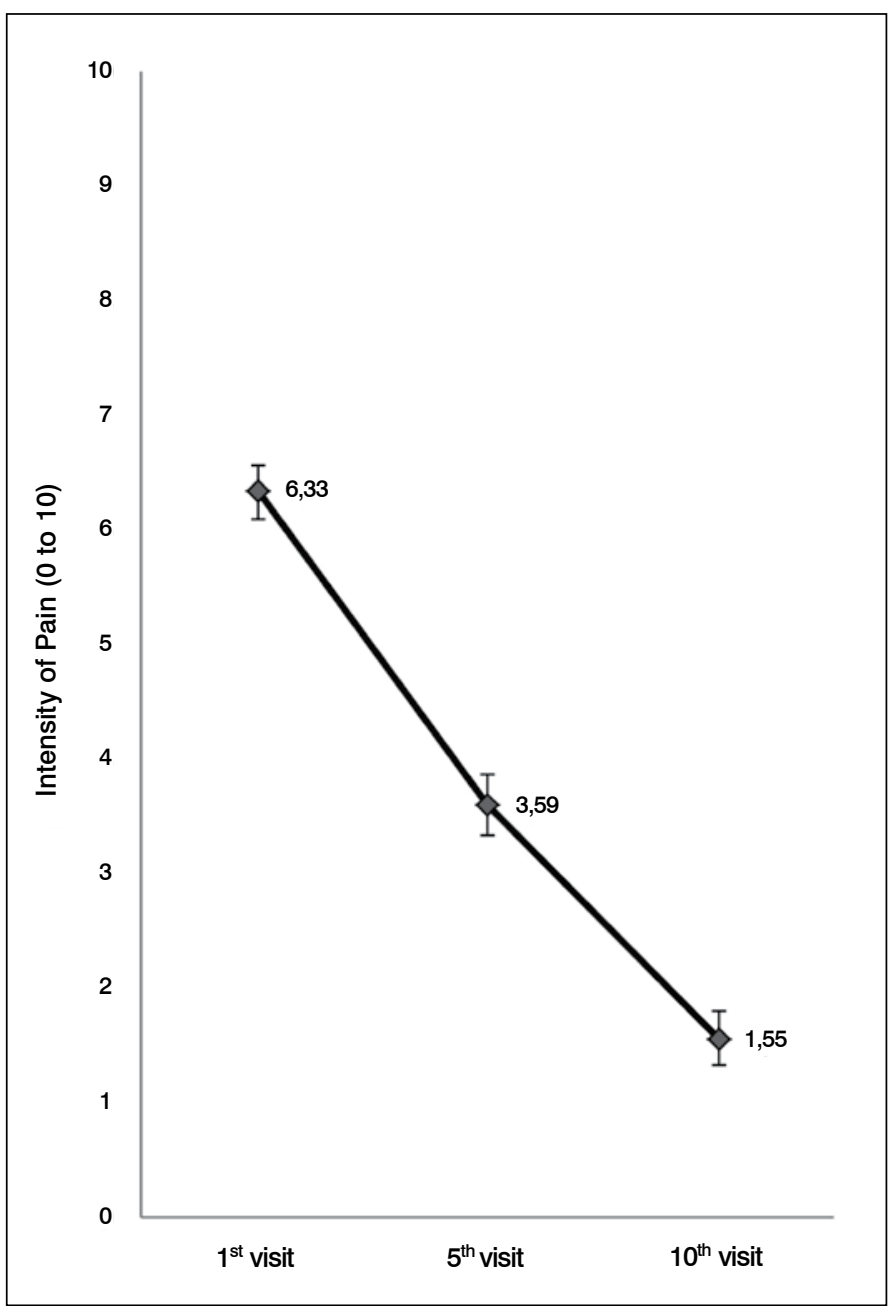

Figure 7. Intensity of cervical pain in the $1^{\text {st }}, 5^{\text {th }}$ and $10^{\text {th }}$ visits recorded through a VAS. Significant differences between the 1st visit and the remaining visits; and between the $5^{\text {th }}$ and $10^{\text {th }}$ visits $(p<0.01)$.

Numerous studies have shown that patients with mechanical neck pain have reduced ROM. ${ }^{10-12,14,15,23}$ The scores considered ideal, through the test performed with the inclinometer, for each movement of the cervical spine in healthy adults, are 60 in cervical flexion, 70 in extension, 45 in lateral flexion, and 80 in rotation. ${ }^{19,24}$ The test to assess cervical ROM may be a useful tool for describing the disability of patients with dysfunction in joints of the cervical spine, and serves as a basis for evaluating the effectiveness of a therapeutic program. ${ }^{10,23,25}$ The results of this study demonstrated that the vertebral manipulations in the cervical and thoracic spine caused a return to cervical ROM at values very close to those considered normal.

The cervical spine is a region where stability is sacrificed in favor of mobility, so this segment, in particular, is more susceptible to lesions. ${ }^{26}$ The mechanical stability of the cervical spine comes from the osteoligamentous and muscular system. Thus, $20 \%$ of the stabilization is provided by the osteoligamentous system, acting near the end of range of movement, while the remaining $80 \%$ comes from the deep muscles of the cervical spine, acting between the beginning and middle of the range of movement, which is commonly adopted during the tasks of daily living. ${ }^{27}$

Giles and Muller, ${ }^{28}$ in a randomized clinical trial, compared the effectiveness of spinal manipulation, medications and acupuncture in patients with cervical and lumbar pain. They concluded that if there are no contraindications, the manipulation generates a greater reduction in pain and a greater increase in joint mobility.

Cassidy et al. ${ }^{29} \mathrm{compared}$ spinal manipulation and mobilization. 
They showed that spinal manipulation was more effective than mobilization in reducing pain in patients with mechanical neck pain, but that both treatments increased the range of cervical movement in similar form. However, Martínez et al., ${ }^{30}$ in their research, reported that spinal manipulation led to an increase in ROM and a greater reduction in pain, compared with cervical mobilization. Therefore, they concluded that spinal manipulation was more effective than mobilization.

On the other hand, Hurwitz et al. ${ }^{31}$ suggest that the mobility of the cervical spine is as effective as manipulation in reducing cervical pain. Hoving ${ }^{32}$ noted that in patients with subacute and chronic neck pain, a better result was obtained, in terms of recovery, in the manual therapy group (manipulation and/or mobilization) than for physical therapy or general practitioner (analgesics, education and advice) at seven weeks of treatment, but not at the end of one year. Hoving et al. ${ }^{32}$ suggest that after treatment with manual therapy, there was an acceleration in recovery in the short term. General medical treatment and physical therapy achieved better long-term outcomes; however, the differences between the three treatment groups at 12 months of follow-up were small, and not statistically significant. In addition, Pikula ${ }^{33}$ found a greater reduction in pain and increased cervical ROM with cervical manipulation, compared with a placebo group.

Vernon et al.,"34 also conducted a study comparing spinal manipulation and the placebo effect. Patients with chronic mechanical neck pain were evaluated for pain threshold to pressure on sensitive points in the paravertebral zone surrounding a manipulable spinal cord injury. In the group that received spinal manipulation, there was a significant change in pain thresholds to pressure. In the placebo group, no change was found in any of the pain thresholds to pressure. This study confirms that manipulation can increase local paraspinal levels of pain threshold. Using a pressure pain threshold gauge, it was possible to determine this beneficial effect on the deep tissues.

Moodley and Brantingham ${ }^{35}$ found greater pain reduction and increased cervical ROM in patients with mechanical neck pain after vertebral manipulation, in a comparison of ultrasounds. The results indicated that spinal adjustments were more effective.

On the clinical efficacy of chiropractic treatment, the most recent report, conducted jointly by Mercer Health and Benefits (the world's biggest health economy consultant) and Harvard University was published in 2009, reviewing studies from both the EU and the USA. Almost half of Americans with spinal pain visit a chiropractor, and the costs of this disability are as high as $\$ 85,000$ million. Countless studies and reviews throughout the world demonstrate that this is the main cause of absenteeism and the most costly in economic terms. ${ }^{36,37}$ The Mercer report concludes that chiropractic medicine is more effective than other treatments for back pain, and the most effective treatment for neck pain, showing a high cost-effectiveness benefits in the treatment of both disorders.

The results published to date in relation to cervical spinal disorders cervical ${ }^{38}$ recommend chiropractic treatment for neck pain, headache of cervical origin, and whiplash syndrome. Despite clinical evidence of the benefits and apparent widespread use of spinal manipulation, the neurophysiological mechanisms underlying its effects are not entirely clear, but this does not negate the clinical effects of spinal manipulation.

According to Ortega Santiago et al., ${ }^{39}$ neck pain is associated with mechanical instability, and can be caused by an increase in nociceptive discharge of the afferent fibers in the vertebral zygapophyseal joints, intervertebral discs, paraspinal muscles, and soft tissues. Fernández de Las Peñas et al., ${ }^{40}$ explain that spinal manipulation can affect the mobility of a hypomobile segment, and produces increased range of movement. Haavik and Murphy ${ }^{41}$ add that the effectiveness of spinal manipulation is due to the fact that manipulation can increase the range of movement of the joints, increasing the activity of the proprioceptive fibers and thereby reducing the transmission of pain stimuli, also relieving chronic tension and spinal nerve irritation caused by joint dysfunction; it relaxes the muscles due to stretching of the joint capsules, which stimulates mechanoreceptors, decreasing muscle soreness. In addition, joint adhesions can be reduced in chronic cases, increasing the pain threshold in the skin and the pain threshold to pressure in the paraspinal muscles.

Leach $^{42}$ and Gatterman ${ }^{43}$ believe the biomechanical changes caused by spinal manipulation have physiological consequences, through their effects on the influence of sensory information to the central nervous system. The afferences to the muscle spindles, and the afferences to the Golgi tendon organs are stimulated by spinal manipulation. Sensory nerve fibers of smaller diameter are likely to become active, although this has not been directly demonstrated. Pickar ${ }^{44}$ hypothesized that the reasons underlying the biomechanical changes in the spine affect the afferent neurons, with a subsequent change in central processing, and affecting the somatomotor efferences and the somatovisceral reflexes.

Spinal manipulation triggers changes in the musculoskeletal system. Experimental tests indicate that the charge of the impulse of a spinal manipulation influences the proprioceptive primary afferent neurons in the paraspinal tissues. ${ }^{44}$ addition, the manipulation can affect the processing of pain, possibly by altering the central facilitated state of the spinal cord, and can affect motor control system. ${ }^{41}$ It is likely that more than one mechanism explains the neurophysiological mechanisms of vertebral manipulation. ${ }^{44}$

\section{CONCLUSIONS}

The subjects of this study had mechanical neck pain and limited cervical ROM in at least one cervical movement. The results of this study suggest that vertebral manipulation, using the Gonstead and Diversified DTV techniques, in the cervical and thoracic spine, could cause a subjective reduction in pain and produce a considerable increase in cervical ROM in adults with mechanical neck pain.

Despite the promising results, the limitations of this study should be emphasized. The population included, has been recruited in a single chiropractic center, which could limit the extrapolation of the results, as the subjects may have specific clinical and demographic characteristics. Other studies with comparison groups and wider samples, outlining specific methodologies through the elimination of variables, are necessary to corroborate the results of this study, before any relationship of cause and effect can be determined.

All authors declare no potential conflict of interest concerning this article.

\section{REFERENCES}

1. Paz JBM. Monografías médico-quirúrgicas del aparato locomotor. Cervicobraquialgia. Barcelona: Masson; 2000

2. Buckle PW, Devereux JJ. The nature of work-related neck and upper limb musculoskeletal disorders. Appl Ergon. 2002;33(3):207-17.

3. Franco ML. Bloqueos diagnóstico-terapéuticos de carillas articulares cervicales. Rev Soc Esp Dolor. 2009;16(2):116-21.

4. Strimpakos N. The assessment of the cervical spine. Part 1: Range of motion and proprioception. J Bodyw Mov Ther. 2011;15(1):114-24.

5. Lu Y, Chen C, Kallakuri S, Patwardhan A, Cavanaugh JM. Neurophysiological and biomechanical characterization of goat cervical facet joint capsules. J Orthop Res. 2005;23(4):779-87.

6. Falco FJ, Erhart S, Wargo BW, Bryce DA, Atluri S, Datta S, et al. Systematic review of diagnostic utility and therapeutic effectiveness of cervical facet joint interventions. Pain Physician. 2009:12(2):323-44

7. Organización Mundial de la Salud (OMS). "Directrices Sobre Formación Básica e Inocuidad en Quiropráctica". Ginebra: OMS; 2006

8. Côté P, Cassidy JD, Carroll L. The Saskatchewan Health and Back Pain Survey. The prevalence of neck pain and related disability in Saskatchewan adults. Spine (Phila Pa 1976). 1998;23(15):1689-98.

9. Guez M, Hildingsson C, Nilsson M, Toolanen G. The prevalence of neck pain: a population-based study from northern Sweden. Acta Orthop Scand. 2002;73(4):455-9.

10. Hagen KB, Harms-Ringdahl K, Enger NO, Hedenstad R, Morten H. Relationship between 
subjective neck disorders and cervical spine mobility and motion-related pain in male machine operators. Spine (Phila Pa 1976). 1997;22(13):1501-7.

11. Triano JJ. Biomechanics of spinal manipulative therapy. Spine J. 2001:1(2):121-30.

12. Lee H, Nicholson LL, Adams RD. Neck muscle endurance, self-report, and range of motion data from subjects with treated and untreated neck pain. J Manipulative Physiol Ther. 2005:28(1):25-32.

13. McNair PJ, Portero P, Chiquet C, Mawston G, Lavaste F. Acute neck pain: cervical spine range of motion and position sense prior to and after joint mobilization. Man Ther. 2007;12(4):390-4.

14. Woodhouse A, Vasseljen O. Altered motor control patterns in whiplash and chronic neck pain. BMC Musculoskelet Disord. 2008;9:90.

15. De Loose V, Van den Oord M, Burnotte F, Van Tiggelen D, Stevens V, Cagnie B, et al. Danneels $\mathrm{L}$, Witvrouw E. Functional assessment of the cervical spine in F-16 pilots with and without neck pain. Aviat Space Environ Med. 2009;80(5):477-81.

16. González-Iglesias J, Fernández-de-las-Peñas C, Cleland JA, Gutiérrez-Vega Mdel R. Thoracic spine manipulation for the management of patients with neck pain: a randomized clinical trial. J Orthop Sports Phys Ther. 2009;39(1):20-7.

17. Lau HM, Wing Chiu TT, Lam TH. The effectiveness of thoracic manipulation on patients with chronic mechanical neck pain - a randomized controlled trial. Man Ther. 2011:16(2):141-7.

18. Dvir $Z$, Werner $V$, Peretz $C$. The effect of measurement protocol on active cervical motion in healthy subjects. Physiother Res Int. 2002;7(3):136-45

19. Hoppenfeld S. Propedêutica ortopédica: coluna e extremidades. São Paulo: Atheneu; 2004

20. Saraiva CM. Manual de técnicas quiroprácticas. Novo Hamburgo, RS: Ed. Feevale; 2004.

21. Cooperstein R. Gonstead Chiropractic Technique (GCT). J Chiropr Med. 2003;2(1):16-24.

22. Cantera CL. Palpaçao: técnicas e procedimentos quiroprácticos. Novo Hamburgo, RS: Ed. Feevale; 2006

23. Cagnie B, Cools A, De Loose V, Cambier D, Danneels L. Reliability and normative database of the Zebris cervical range-of-motion system in healthy controls with preliminary validation in a group of patients with neck pain. J Manipulative Physiol Ther. 2007;30(6):450-5.

24. Norkin CC, White J. Medida do movimento articular. 2a. ed. Porto Alegre: Artes Médicas; 1997.

25. Cipriano JJ. Photographic manual of regional orthopedic and neurologic tests. 5th ed. Philadelphia: Lippincott Williams \& Wilkins; 2010.

26. Magee DJ. Avaliação musculoesquelética. 4a. ed. Barueri, SP: Manole; 2005.

27. Panjabi MM, Cholewicki J, Nibu K, Grauer J, Babat LB, Dvorak J. Critical load of the human cervical spine: an in vitro experimental study. Clin Biomech (Bristol, Avon). 1998;13(1):11-17.

28. Giles LG, Muller R. Chronic spinal pain: a randomized clinical trial comparing medication, acupuncture, and spinal manipulation. Spine (Phila Pa 1976). 2003;28(14):1490-502.

29. Cassidy JD, Lopes AA, Yong-Hing K. The immediate effect of manipulation versus mobilization on pain and range of motion in the cervical spine: a randomized controlled trial. $J$ Manipulative Physiol Ther. 1992;15(9):570-5
30. Martínez-Segura R, Fernández-de-las-Peñas C, Ruiz-Sáez M, López-Jiménez C, Rodríguez-Blanco C. Immediate effects on neck pain and active range of motion after a single cervical high-velocity low-amplitude manipulation in subjects presenting with mechanical neck pain: a randomized controlled trial. J Manipulative Physiol Ther. 2006;29(7):511-7.

31. Hurwitz EL, Morgenstern H, Harber P, Kominski GF, Yu F, Adams AH. A randomized trial of chiropractic manipulation and mobilization for patients with neck pain: clinical outcomes from the UCLA neck-pain study. Am J Public Health. 2002;92(10):1634-41.

32. Hoving JL, Koes BW, de Vet HC, van derWindt DA, AssendelftWJ, van Mameren $\mathrm{H}$, et al. Manual therapy, physical therapy, or continued care by a general practitioner for patients with neck pain. A randomized, controlled trial. Ann Intern Med. 2002;136(10):713-22.

33. Pikula JR. The effect of spinal manipulative therapy (SMT) on pain reduction and range of motion in patients with acute unilateral neck pain: a pilot study. J Can Chiropr Assoc. 1999;43:111-9.

34. Vernon HT, Aker P, Burns S, Viljakaanen S, Short L. Pressure pain threshold evaluation of the effect of spinal manipulation in the treatment of chronic neck pain: a pilot study. $J$ Manipulative Physiol Ther. 1990;13(1):13-6.

35. Moodley M, Brantingham JW. The relative effectiveness of spinal manipulation and ultrasound in mechanical pain: Pilot study. J Chiropr Med. 2002;1(4):184-8.

36. Coudhry, N, Milstein, A. "Do Chiropractic Physician Services for Treatment of Low-Back and Neck Pain Improve the Value of Health Benefit Plans? An Evidence-Based Assessment of Incremental Impact on Population Health and Total Health Care Spending." Harvard Medical School, Boston, Mercer Health and Benefits, San Francisco; 2009.

37. Centers for Disease Control and Prevention (CDC). Prevalence and most common causes of disability among adults--United States, 2005. MMWR Morb Mortal Wkly Rep. 2009;58(16):421-6.

38. Haldeman S, Carroll L, Cassidy JD, Schubert J, Nygren A: Bone and Joint Decade 20002010 Task Force on Neck Pain and Its Associated Disorders. The Bone and Joint Decade 2000-2010 Task Force on Neck Pain and Its Associated Disorders: executive summary. Spine (Phila Pa 1976). 2008:33(Suppl 4):S5-7.

39. Ortega-Santiago R, Martínez-Segura R, Llave-Rincón, Al, Pérez-Bruzón JD, Fernández-de-Las-Peñas C. Efectos hipoalgésicos y de movilidad cervical tras la manipulación vertebral dorsal en pacientes con cervicalgia mecánica subaguda: estudio piloto. Fisioter. 2012;34(2):51-8.

40. Fernández de las Peñas C, Downey C, Miangolarra Page J. Immediate changes in radiographically determined lateral flexion range of motion following a single cervical HVLA manipulation in patients presenting with mechanical neck pain: a case series. Int J Osteopath Med. 2005;8:139-45.

41. Haavik H, Murphy B. The role of spinal manipulation in addressing disordered sensorimotor integration and altered motor control. J Electromyogr Kinesiol. 2012;22(5):768-76.

42. Leach RA. The chiropractic theories. 3rd ed. Baltimore: Williams and Wilkins; 1994

43. Gatterman MI. Foundations of chiropractic. St. Louis: Mosby; 1995.

44. Pickar JG, Bolton PS. Spinal manipulative therapy and somatosensory activation. J Electromyogr Kinesiol. 2012;22(5):785-94. 